\title{
パルス電圧印加変調測光法を応用したグロー放電発光分析法による 鋼中の微量合金元素の高精度定量法
}

\author{
我妻 和 明 $^{1}$
}

\begin{abstract}
Precise determination of minor alloyed elements in steel by glow discharge optical emission spectrometry with pulsed-voltage modulation technique
\end{abstract}

Kazuaki WAGATSUMA $^{1}$

${ }^{1}$ Institute for Materials Research, Tohoku University, 2-1 - 1, Katahira, Sendai-shi. Miyagi 980 - 8577

(Received 15 July 2003, Accepted 6 November 2003)

\begin{abstract}
A pulsed-voltage was applied to a glow discharge lamp for a modulation detection technique in d.c. glow discharge optical emission spectrometry. Emission signals from the glow discharge plasma were modulated by a cyclic variation in the discharge voltage so that only the desired signals would be detected without any noise with a lock-in amplifier. Molybdenum and vanadium determinations in a steel sample having contents of several 0.001 mass $\%$ was performed to estimate the analytical precision. The relative standard deviations of the intensities of the Mo I $379.65 \mathrm{~nm}$ and the V II $310.10 \mathrm{~nm}$ were $0.2 \sim 0.6 \%$ in the modulation method, whereas they were $2.6 \sim 3.6 \%$ in a conventional detection method. Compared with the result by the conventional detection method, the modulation method yielded a better precision in the analytical values. This technique contributes to the precise determination of minor elements alloyed in steels.
\end{abstract}

Keywords : glow discharge optical emission spectrometry; voltage modulation; precision ; minor alloyed element; molybdenum; vanadium; steel.

\section{1 緒 言}

鋼材料はその用途に応じて様々な種類が実用に供されて おり，社会基盤を支える材料として不動の地位を占めてい る.その特性を決める因子として鉄基材に添加される合金 元素の種類と量が重要であり, 強度やじん性の向上のため に Mo, $\mathrm{V}, \mathrm{Nb}, \mathrm{Ti}, \mathrm{Mn}, \mathrm{Cr}$ 等, 耐蝕性や耐候性の向上 のために $\mathrm{Ni}, \mathrm{Cr}, \mathrm{Cu}, \mathrm{Si}$ 等, また耐熱性の向上のために $\mathrm{Ni}, \mathrm{Co}, \mathrm{W}, \mathrm{Mo}$ 等, 多種多様な合金元素が用いられ, そ の添加量も 0.01 数十\% と広濃度範囲にわたっている ${ }^{1)}$. 製鋼プロセスにおいては，このような合金元素の添加量を 厳密に制御することが求められ，その工程管理に用いられ るオンサイト分析法は極めて重要な役割を果たしてい

\footnotetext{
${ }^{1}$ 東北大学金属材料研究所：980-8577 宮城県仙台市青葉区片平 2-1-1
}

$ろ^{2)}$.

鉄鋼製造過程においては，オンサイト分析法としてスパ ーク放電発光分析法（通称，カウントバック法）が従来法 として用いられてきた ${ }^{3)}$. カウントバック法は, 多元素を 同時にかつ短時間で定量分析できるという優れた特徵を有 するため，工程管理に適する方法として今日まで製鋼プロ セスを支えてきた分析技術である．しかしながら，最近の 精錬・精製技術の進歩によりカウントバック法だけでは対 応が難しい分析対象が出現してきた。その一つは，鋼の高 純度化による不純物元素の低減に伴い，カウントバック法 の検出感度では定量が困難な極微量元素群である ${ }^{4)}$.もう 一つは本研究の対象であるが, 高精度定量が必要とされる 合金添加元素群である，後者は，所定の特性を得るために 添加元素の量を厳密に制御する必要性と, 添加される元素 は一般に高価であるため経済性からの要求によるものであ 


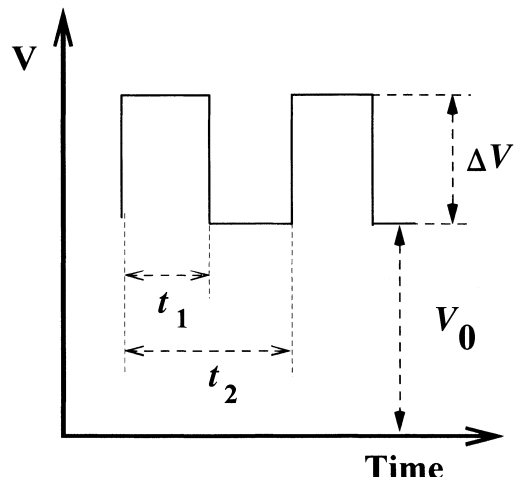

Fig. 1 Schematic wave pattern of the discharge voltage applied

る.このような新規の分析要求に対応するため, カウント バック法より優れた分析特性, より高い分析感度及び分析 精度を持つオンサイト分析法の開発は，製鋼プロセスにお いて緊急の課題となっている

グロー放電発光分析法は，固体試料を直接分析できるた め工程管理用のオンサイト分析法として使用できる ${ }^{6)}$. ま た，グロー放電はスパーク放電と異なり持続型の安定放電 であるため，一般に，グロー放電を励起源とした発光分析 は良好な分析精度を与える。しかしながら，上述したよう な製鋼工程管理分析に完全に対応するためには，グロー放 電発光分析法においても励起源や測定方法の改良等の研究 が求められる.

変調測光法はこのような課題を解決するための方法の一 つである ${ }^{7)}$. 特に, グロー放電管は放電電圧に周期的な変 動成分を重盢することが容易にできることから，その分析 特性を向上させるために採用することができる有力な選択 肢である，この場合変調測光法を用いると，放電電圧の周 期的な変動に同期して変化する信号成分のみを選択的に検 出することができる．これはロックインアンプによる位相 敏感検波法により実現され，このとき，その周期成分と異 なる周波数を持つ雑音成分等は完全に除去することができ る。この特性により, 雑音に対する信号強度比（SNR, signal-to-noise ratio）は大幅に向上するため, 検出限界及 び分析精度の向上に寄与するものと考えられる。

既報において，グロー放電管に変調測光法を適用した場 合の分光特性 ${ }^{8)}$, 及び分析応用として高周波グロー放電励 起源におけるバイアス電圧 ${ }^{9)}$ ・バイアス電流 ${ }^{10)}$ の変調測光 法, 更に直流グロー放電励起源を用いた鋼中の微量リン・ 硫黄の定量について報告した ${ }^{11)}$. 以上の分析応用はいずれ も検出下限の改善を目的としたものであった。本報では, 分析精度の改善という観点から直流グロー放電励起源に変 調測光法を適用し，鋼中の $0.001 \%$ オーダーの Mo, V を 定量した場合の結果について, 通常測光法と変調測光法と の間で繰り返し再現性の比較を行った結果を報告する.
2 実験

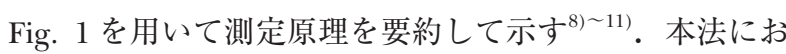
いては，測定される光信号に変調成分を作るため，直流電 圧 $\left(V_{0}\right)$ に一定の振幅幅を持つ交番電圧 $(\Delta V)$ を重畳し て放電管に印加する。このとき，放電管内で起こる試料導 入過程（陰極スパッタリング） 及び試料原子の励起過程共 に交番電圧の周波数 $(f)$ に追随して変動する。その結果 として，試料原子からの発光線強度はその周波数に同期す る変調成分を持つことになる。変調成分はロックインアン プにより選択的に検出することができるため，変調成分以 外の雑音等は完全に除去され，目的信号の SNR の改善に 大きく寄与する．Fig. 1 から電圧変調法における実験因子 としては, 直流バイアス電圧 $\left(V_{0}\right)$, 交番電圧 $(\Delta V)$, 周 波数 $(f)$ ，及びデューティ比 $\left(t_{1} / t_{2}\right)$ がある. 本稿では， 特にデューティ比を実験因子として分析特性を検討した結 果を報告する.

実験装置に関しては既に報告している ${ }^{11)}$ 。既報と異なる 装置として, 交番電圧を発生させるために電力増幅器 (Model-4502, NF Electronics Corp. 製) を使用した。こ れは土200 V までの交番電圧を発生させることができ，既 報で使用したもの ${ }^{11)}$ と比較して 3 倍のピーク電圧を持つ交 番電圧を放電管に印加することができる.

検量線作成のための試料として，機器分析用鋼標準試料 （No. 150 検量線シリーズ，日本鉄鋼連盟）から No. 151-1 を使用した。この試料中の Mo 及びVの検定值はそれぞ れ 0.053 mass\% と 0.057 mass\% である。 また，定量分析 に供した試料は低炭素鋼試料（GK-1012，日本鉄鋼協会関 西支部）であり，Mo 及び V の推奨分析值はそれぞれ 0.005 mass\% と 0.002 mass\%であることが示されている.

\section{3 結果と考察}

Fig. 2 は No. 151-1（Mo 0.053 mass\%）を試料とした場 合の Mo I $379.65 \mathrm{~nm}(\mathbf{O}$, ○）とそのバックグラウンド 波長位置として $379.74 \mathrm{~nm}(\boldsymbol{\Delta}, \triangle)$ の発光強度の時間変 化を測定したものである。通常測光法（a）と変調測光法 （b）を用いて同時に得たデー夕を記録した。また，放電 条件として $t_{1} / t_{2}=50 \%, \Delta V=200 \mathrm{~V}(\boldsymbol{O}, \boldsymbol{\Delta})$ と $t_{1} / t_{2}=$ $30 \%, \Delta V=300 \mathrm{~V}(\bigcirc, \triangle)$ の 2 種類を選択した場合の データを示している. 通常測光法では，カットオフ周波数 が $0.4 \mathrm{~Hz}$ （24 dB/oct）のローパスフィルターを使用して 平均発光強度を得た。また，変調測光法においては，ロッ クインアンプの時定数を 10 秒 \{この值はカットオフ周波 数が $0.02 \mathrm{~Hz}$ (6 dB/oct) のバンドパスフィルタに相当す る\}に設定した。Fig. 2 から明らかなように，変調測光 法で得られた発光強度の変動は, 通常測光法に比較して大 幅に小さくなっており，相対標準偏差（RSD）の低減，し 


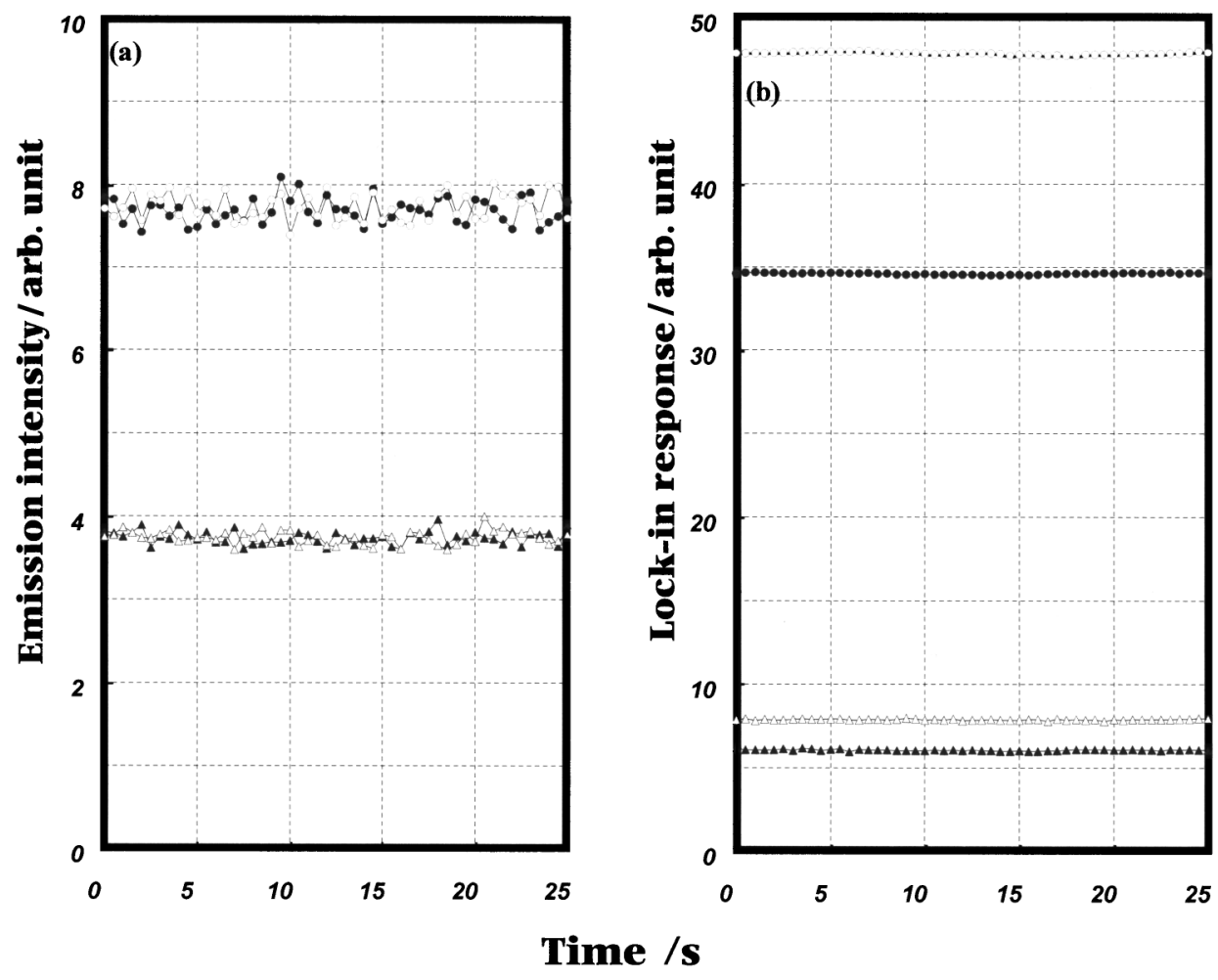

Fig. 2 Time dependence of the emission intensities measured with DC amplification method (a) and modulation detection method (b)

Analytical line: Mo I $379.65 \mathrm{~nm}$ (circle); background position: $379.74 \mathrm{~nm}$ (triangle); sample: low-alloyed steel containing 0.053 mass \% Mo (No. 151-1, The Iron and Steel Institute of Japan): alternating voltage/duty ratio: $200 \mathrm{~V} / 50 \%$ (solid symbols) and 300 $\mathrm{V} / 30 \%$ (open symbols); bias voltage: $350 \mathrm{~V}$; frequency: $217 \mathrm{~Hz}$; plasma gas: Ar at 530 $\mathrm{Pa}$

たがって測定精度の改善に大きく寄与するものとなる。こ の場合 $\left(t_{1} / t_{2}=50 \%, \Delta V=200 \mathrm{~V}\right)$ の RSD を個別に評価 すると，通常測光法では $1.6 \%$ であるのに対して変調測光 法では $0.11 \%$ となった，通常測光法において，使用する ローパスフィルターのカットオフ周波数を小さくすること により，RSDを更に改善できると期待される。しかしな がら，カットオフ周波数を低くするためには大きな静電容 量を持つコンデンサーを使用する必要があり，また良好な 遮断特性を得るためにはアクティブフィルター回路を使用 する必要があるが，それ自身からのノイズの影響も存在す る. 更に通常測光法の場合には, 信号情報は純粋な直流成 分のみに含まれているのではないため，必要以上に透過周 波数帯を狭くすると，目的信号の情報も失われる恐れがあ る，以上の上うな理由により，通常測光法に扔けるローパ スフィルターのカットオフ周波数は制限を受け極端に小さ な值を選択することはできない．

Fig. 2(a) から明らかなように, 通常測光法では 2 種の 放電条件において発光強度はほぼ同一である。これら 2 種類の放電条件では放電管から発せられる発光線の平均強 度はほぼ等しいのに対して, 変調測光法では検出強度に大 小関係が生じている。これは, 交番電圧とデューティ比の
選択により変調成分に差異があることを示しており，変調 測光法ではこれら 2 つの実験因子の最適化が重要である と考えられる. Fig. 2(b) の結果は, デューティ比を小さ な值とし大きな交番電圧とする放電（パルス状電圧）を用 いた場合に，より良好な分析特性が得られることを示唆し ている.

通常測光法と変調測光法を比較した場合, 信号強度に比 ベてバックグラウンド強度は後者のほうが相対的に小さい 值を示すことが分かる。これは，バックグラウンドに対す る信号強度比（SBR， signal-to-background ratio）を改善 し，良好な分析特性を与える。この場合（ $t_{1} / t_{2}=50 \%$ ， $\Delta V=200 \mathrm{~V})$ のSBR を個別に評価すると，通常測光法で は 2.0 であるのに対して変調測光法では 5.8 となった。こ の現象は次のように解釈できる。試料原子からの発光は, スパッタリング過程と励起過程を経た結果として得られる ものであり，グロー放電励起源に交番電圧を印加するとそ の両者が変調を受けるのに対して，バックグラウンド発光 はプラズマガスからの発光と同様に励起過程のみの変調に より観測されるものである。したがって，試料原子からの 発光がより強い変調効果を受けるものと考えることができ る。また，直流バイアス電圧（Fig. 1 の $V_{0}$ ）は，変調測 

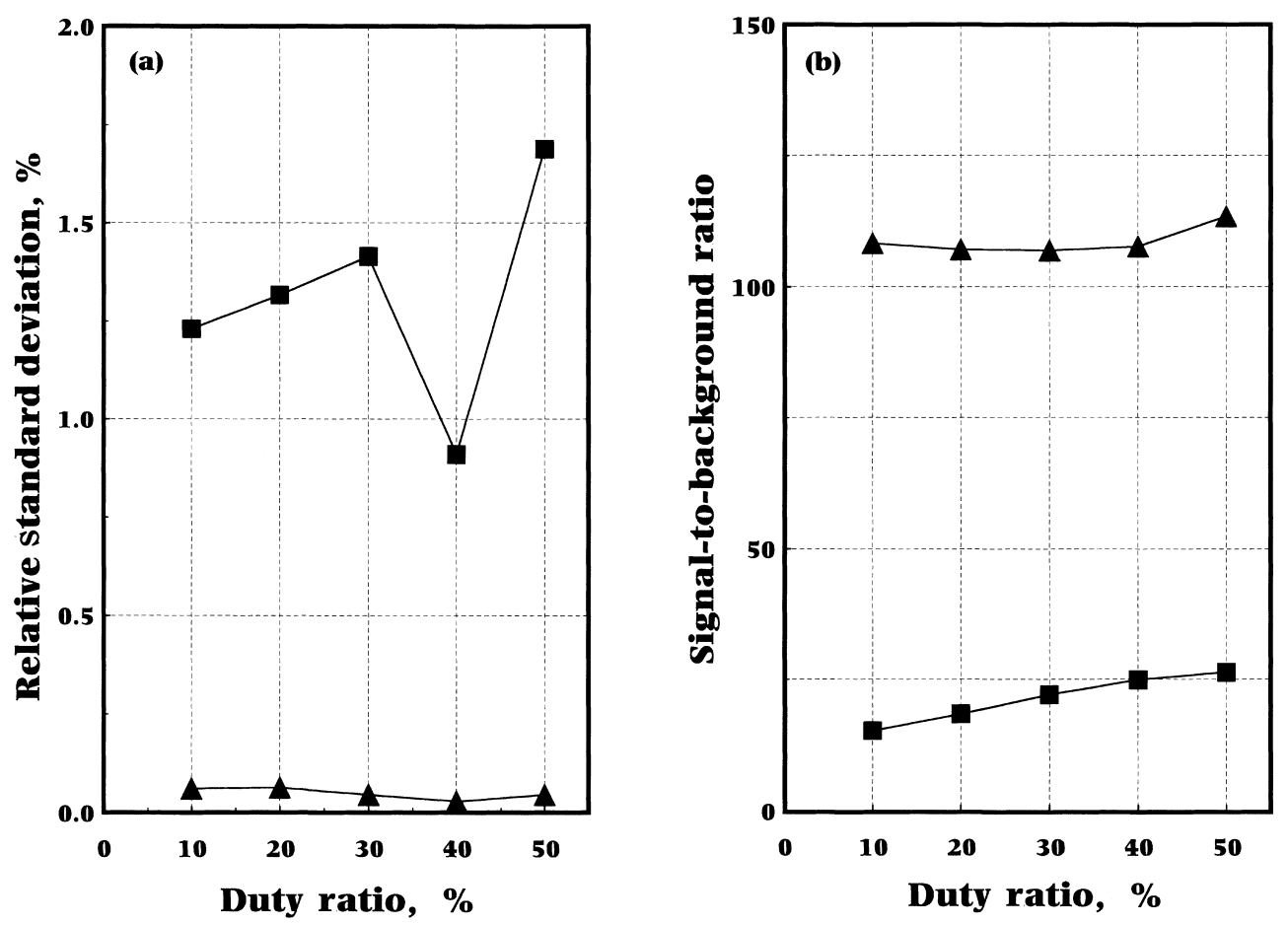

Fig. 3 Dependence of the RSD (a) and the SBR (b) on the duty ratio, measured with DC amplification method (square) and modulation detection method (triangle)

Analytical line: V II $310.10 \mathrm{~nm}$; sample: low-alloyed steel containing 0.43 mass \% V (No. 155-1, The Iron and Steel Institute of Japan): alternating voltage: $200 \mathrm{~V}$; bias voltage : 350 $\mathrm{V}$; frequency: $217 \mathrm{~Hz}$; plasma gas: Ar at $530 \mathrm{~Pa}$

光法におけるSBR を決める実験因子の一つである。これ は, グロー放電管においてはスパッタリングが起こるため のしきい值電圧があり ${ }^{12)}, V_{0}$ をこのしきい值電圧近傍と なるように選択することにより，低電圧周期では試料原子 の導入は停止するためその発光をほとんどゼロにすること ができる.この場合, プラズマ本体は維持されているので プラズマガスからの発光は観測される。したがって, 変調 測光法においては，プラズマガスやバックグラウンドの発 光と比較して試料原子からの発光が強調されて検出される と考えられる ${ }^{11)}$.

Fig. 3 はデューティ比を変化させた場合の V I 309.10 $\mathrm{nm}$ の発光強度測定に関する RSD（a）と SBR（b）を示し たものである. 通常測光法（ロ）と変調測光法（ム）によ り同時に得たデータを解析したものである. RSD と SBR 共にデューティ比の值にかかわらず, 変調測光法を用いた 場合に優良な分析特性を与えることが分かる. 変調測光法 の場合の RSD は $0.06 \%$ 以下であるのに対して, 通常測光 法における RSD は $0.9 \sim 1.6 \%$ となっている. SBR は通常 測光法ではデューティ比に従って増加するが, 変調測光法 を用いた場合はほぼ一定で 100 以上の值を示す。このこ とは，デューティ比を低く抑えても良好な分析特性を維持 できることを示唆しており, 変調測光法の重要な特性であ ると考えられる。デューティ比が小さいほどサンプリング
量を少なく抑えることができるため，放電管の内部污れに よる放電条件の変化を抑えることが可能で, 長時間安定な 条件で分析操作を行うことができる．また，これはスパッ タリング速度を抑制するため薄膜試料の深さ方向分析に極 めて有効であり ${ }^{13)}$ ，分析特性を悪化させることなくスパッ タリング速度を制御する方法として推奨できる。

No. 151-1 標準試料を基準として，Mo，Vそれぞれにつ いて 2 つの異なった放電条件, $t_{1} / t_{2}=50 \%, \Delta V=200 \mathrm{~V}$ と $t_{1} / t_{2}=30 \%, \Delta V=300 \mathrm{~V}$ を採用して検量線を作成した. 更にこの検量線を用いて GK-1012 試料中の Mo, Vの含有 量について定量した. Table 1 及び 2 がその結果である. それぞれの条件について, 30 秒間, 発光強度を測定して 等時間間隔で 11 点サンプリングしてその平均值と標準偏 差を算出し, その結果より定量值とその相対標準偏差を求 めた。またそのときの SBR 值も合わせて表中に示す。更 に, それぞれの放電条件で独立 2 回の定量操作を行い, 繰り返し再現性を評価した。

いずれの場合においても, RSD, SBR ともに通常測光法 と比較して変調測光法において良好な結果を得た。また, 繰り返し再現性は, $\mathrm{V}$ 定量の場合には通常測光法，変調測 光法両者共に 2 回の測定結果に良い一致が認められる. しかしながら, Mo 定量の場合には, 変調測光法では 2 回 の測定結果が一致しているのに対して，通常測光法の 2 
Table 1 Comparison in the analytical results for molybdenum determination in a low-alloyed steel between DC detection and voltage modulation method

\begin{tabular}{|c|c|c|c|c|c|c|c|}
\hline \multirow{2}{*}{ Sample } & \multirow{2}{*}{$\begin{array}{l}\text { Recommended } \\
(\text { mass } \%)\end{array}$} & \multirow{2}{*}{$\begin{array}{l}\text { Exp. conditions } \\
\text { Alternating voltage/Duty ratio }\end{array}$} & \multirow{2}{*}{ Measuring method } & \multicolumn{4}{|c|}{ Found } \\
\hline & & & & $n$ & mass $\%$ & $\mathrm{RSD}, \%$ & SBR \\
\hline \multirow[t]{8}{*}{ GK-1012 } & Mo 0.005 & $200 \mathrm{~V} / 50 \%$ & DC & 11 & 0.00579 & 3.121 & 0.128 \\
\hline & & & & 11 & 0.00546 & 3.567 & 0.121 \\
\hline & & & AVM & 11 & 0.00609 & 0.610 & 0.720 \\
\hline & & & & 11 & 0.00601 & 0.570 & 0.710 \\
\hline & & $300 \mathrm{~V} / 30 \%$ & $\mathrm{DC}$ & 11 & 0.00509 & 3.320 & 0.115 \\
\hline & & & & 11 & 0.00454 & 2.611 & 0.103 \\
\hline & & & AVM & 11 & 0.00632 & 0.569 & 0.814 \\
\hline & & & & 11 & 0.00625 & 0.544 & 0.805 \\
\hline
\end{tabular}

Table 2 Comparison in the analytical results for vanadium determination in a low-alloyed steel between DC detection and voltage modulation method

\begin{tabular}{|c|c|c|c|c|c|c|c|}
\hline \multirow{2}{*}{ Sample } & \multirow{2}{*}{$\begin{array}{l}\text { Recommended } \\
\qquad(\operatorname{mass} \%)\end{array}$} & \multirow{2}{*}{$\begin{array}{l}\text { Exp. conditions } \\
\text { Alternating voltage/Duty ratio }\end{array}$} & \multirow{2}{*}{ Measuring method } & \multicolumn{4}{|c|}{ Found } \\
\hline & & & & $n$ & $\operatorname{mass} \%$ & $\mathrm{RSD}, \%$ & SBR \\
\hline \multirow[t]{8}{*}{ GK-1012 } & V 0.002 & $200 \mathrm{~V} / 50 \%$ & DC & 11 & 0.00104 & 2.886 & 0.367 \\
\hline & & & & 11 & 0.00106 & 3.011 & 0.374 \\
\hline & & & AVM & 11 & 0.00100 & 0.227 & 0.737 \\
\hline & & & & 11 & 0.00100 & 0.205 & 0.740 \\
\hline & & $300 \mathrm{~V} / 30 \%$ & DC & 11 & 0.00107 & 3.290 & 0.376 \\
\hline & & & & 11 & 0.00106 & 3.564 & 0.372 \\
\hline & & & AVM & 11 & 0.00096 & 0.158 & 0.695 \\
\hline & & & & 11 & 0.00094 & 0.143 & 0.699 \\
\hline
\end{tabular}

回の測定結果に大きな偏差が生じ明らかに分析精度の悪化 が認められる。これは, 両者の SBR 值を比較すれば明ら かなように，それぞれの分析線，Mo I $379.65 \mathrm{~nm}$ と V I $309.10 \mathrm{~nm}$ の検出強度が異なり, 後者が感度に優れている ことが原因と考えられる.

変調測光法の適用は SBR 及び RSD を改善するため分析 精度の向上に寄与する. 特に, 目的元素の含有量が小さく, 通常測光法では十分な SBR で発光強度を評価できない場 合に有効な測定手段である.

本研究は, (社) 日本鉄鋼協会鉄鋼研究振興助成及び同学会部門 研究会助成を受けて行ったものである。また，川崎製鉄 21 世紀 財団, 理学電機工業 (株), 及び川崎製鉄 (株) 技術研究所 \{ 現, JFE スチール (株) スチール研究所\}より受けた研究助成により研 究設備の一部を購入した。 以上の研究助成に深謝申し上げます.

$$
\text { 文献 }
$$

1）門間改三，須藤 一: “鉄鋼材料とその熱処理”, 第
$8 \sim 15$ 章 $(1974)$, (日本金属学会).

2) 佐伯正夫: “鉄鋼の迅速分析”, 第 2 章 (1998), (地人 書館)。

3) JIS G 1253, 鉄及び鋼, スパーク放電発光分光分析法 (1995).

4) 雀部 実: ふえらむ, 1999, 558.

5) 日本鉄鋼協会編：“製鋼工程管理分析の高速化と高 感度化の研究”, (2001), (日本鉄鋼協会).

6) R. Payling, D. G. Jones, A. Bengtson (Eds.): "Golw Discharge Optical Emission Spectrometry”, (1997), (John Wiley \& Sons, Chirchester).

7) K. Wagatsuma: Appl. Spectrosc. Rev., 37, 223 (2002).

8) K. Wagatsuma, K. Hirokawa: Anal. Chem., 56, 2732 (1984).

9) K. Wagatsuma: Fresenius J. Anal. Chem., 363, 333 (1999).

10) K. Wagatsuma: Anal. Sci., 15, 517 (1999).

11) K. Wagatsuma: ISIJ Int., 42, 783 (2000).

12) P. W. J. M. Boumans: Anal. Chem., 44, 1219 (1972).

13) K. Wagatsuma: Surf. Interface Anal., 27, 63 (1999). 